qualified for registration any certificate of competency or other donment so framed as to bear colourable rescmllance in appearance or phrascology to a diploma conveying a right to act as a medical pracMedical Acts and is accordingly liable to be visited with the condemma-

The Council of the Society has already taken steps with the view of removing all causes of offence, now for the first time specified, from its certificate. This it would have done in the first instance had it received the necessary information. In doing so it by no means acknowledges that such causes of offence are well founded.

\section{AN ANALYSIS OF THE CASES OPERATED UPON WITH THE MURPHY BUTTON UP TO DATE.}

Bx JOHN B. MURPHY, A.M., M.D. CHIC $\Lambda$ Go, PROFESSOR OF SURGERY AND CLINICAL SURGERY, COLI.EGE OF

POST-GRADUATE MEDICAL SCHOOL AND IIOSPITAL, \&C.

A SUFFICIENT time has now elapsed to warrant a complete report of the cases operated on by means of the button and to justify us in drawing conclusions as to the field of its usefulness. The advantages and disadvantages of the device were at first theoretical ; they were later sustained or controverted by the results in experiments and in a small number of cases ; finally, we have now a very large number of cases from which to draw conclusions, and a sufficient number, I believe, to enable us to make valuable deductions for our guidance in the future. We will consider the cases in groups, and we will pay particular attention to the fatal cases, and endeavour to determine the cause of the fatalitywhether it was a result $(a)$ of the disease itself ; $(b)$ of the general condition produced by the disease; $(c)$ of the operation; $(d)$ of failure in obtaining a perfect result at the seat of approximation; $(e)$ of a sequel of the operation; or $(f)$ of intercurrent causes. With this general plan as a gaide we will take up the subject as follows.

Gastro-enterostomy for Maligyant Disease BY LATERAL APPROXIMATION.

Of this variety we had 21 cases with 9 deaths. In the first fatal case the patient had suffered from severe hæmorrhage for four weeks preceding the operation, and it was hoped that by performing a gastro-enterostomy a contraction of the stomach would take place, and possibly hæmostasis. The operation was performed in seven minutes, but the bleeding continued as before and ended fatally four days later. The necropsy showed a perfect approximation. In the second fatal case the patient died of exhaustion forty-eight hours after the operation. A perfect approximation was found. In the third fatal case the patient was very much emaciated and depressed before operation and died twelve hours after. The necropsy showed a perfect approximation. The fourth death occurred from exhaustion in twelve hours. The fifth death was in a case in which the smallest-size button was used, as the operator had no other at the time. The button was so small it was impossible for it to hold a sufficient amount of the tissue to retain the margin of a thick wall, as of the stomach, within its grasp; the wall slipped away from the clasp of the button, and the contents escaped into the peritoneal cavity and caused death. The smallest-size button should never be used in any operation on the stomach. The . sixth death occurred from circumscribed peritonitis on the third day. On post-mortem examination the approximation was perfect, and in the stomach was found a large alcer which was probably the source of the infection. There was also cancer of the pancreas, liver, and other organs, all of which contributed to lessen the resistance of the tissues against infection. In the seventh death the patient died of exhaustion four days after operation. There was perfect approximation, no infection, and the button was still in position. In the eighth fatal case the patient died on the seventh day from general suppurative peritonitis. The necropsy showed perfect approximation and the button still in position; the cause of the peritonitis was not given. The ninth death was from septic peritonitis. The button was not pressed tight enough, and one edge of the stomach had slipped away. It will be noticed that four of the nine deaths were from exhaustion, two from imperfect operation, and three from peritonitis from infection at the time of operation. Are we justified in operating in these extremely emaciated, cachectic patienta with cancer of the pylorns? The patients as a rule survive the operation but a very short peliod of time, when they succumb to the maras. mus of the disease, and not to the effects of obstruction of the pylorus. It is my opinion that patients who are not in a condition to stand a pylorectomy should not be operated on. The relief obtained, even where gastro-enterostomy is successful, is so limited that it does not justify the danger and discomfort produced by the operation, notwithstanding that the operation can be performed with the button in from five to seven minutes. These patients suffer much more from shock in operation than those with nonmalignant disease, and the regenerative power of the tissues in a patient with malignant disease is much impaired. Therefore in this class of cases I scarify with the point of a needle the surfaces of the peritoneum of the stomach and intestinal wall where they are brought in contact; this hastens the primary adhesions and increases the rapidity of definitive union. A few interrupted sutures half an inch from the button between the intestine and stomach may be necessary where there is great traction of the coil of in. testine approximated, but I have so far not found a case in which I considered it indicated. I prefer the Von Hacker position, though the Wölfler may be used. I believe with Dr. Willy Meyer that the former favours the passage of the button into the intestine. If the cancer involves but a small portion of the stomach in the neighbourhood of the pyloras the most satisfactory operation in its ultimate result is a division of the duodenum two inches below the pylorus closing the proximal end with a Czerny-Lombert suture and joining the distal end to the posterior wall of the stomach with the button. In non-malignant strictures of the pylorus this is the only operation that should be performed. Where the approzimation has been made to the anterior wall of the stomach the button has dropped back into the stomach in four cases; in none of them did it give any unpleasant symptoms, and I believe it would have passed as soon as the stomach contracted to its normal size and the patient was up and about. I have not used the oblong button for this operation and do not consider it necessary, as the results so far prove that the opening made by the circular button is ample, and that the scar does not contract. The oblong button has, however, certain merits. It produces a larger opening; it is more easily inserted than the circular, and passes through the intestine with greater freedom as its diameter is only $\frac{5}{8}$ in. The only two cases in which it has been used are the following :-Case reported by Dr. Joseph D. Bryant of New York: "Diagnosis, fæcal fistula of long standing. There had been several previous operations for its closure. Operation, May 9th, 1894. Lateral approximation of ileum to descending colon with oblors

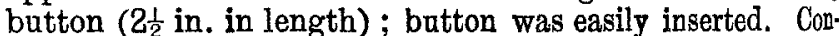
valescence was uneventful. Button passed on tifteenth day." Case reported by Dr. Willy Meyer of New York: "Male aged twenty-two years. Fistula in right inguinal region. History of appendicitis ; abscess opened ; fæcal fistula fol. lowed. Laparotomy, May 31st, 1894. Chronic appendicitis; appendix embedded in dense adhesions, perforated ; resection of appendix; loose tampon; appearance of fistala which baffled treatment. Aug. 16th, 1894, ileo-colostomy by Murphy's oblong button. Its two halves could be tied in with great ease and did not require a longer slit in the gut for insertion than the ordinary button. Recovery. Button voided without any difficalty on the tenth day."

\section{CONCLUSIONS.}

1. Gastro-enterostomy should never be performed on an extremely cachectic patient.

2. The Von Hacker position is preferable.

3. A supporting suture outside of the button is not necessary except for the relief of tension.

4. In non-malignant stricture of the pylorus the end of the duodenum should be united to posterior wall of the stomach.

5. Pylorectomy by the method described below shonld always be resorted to where possible.

6 . 'The patient should receive liquid nourishment immodiately after the effects of the anæsthetic pass away.

\section{PYLORECTOMY.}

Pylorectomy is always the most desirable operation for malignant stricture of the pylorus, as it is the only operation 
that offers hope of prolonging the life of the patient for a considerable time. When it is successful the patient regains his usual vigour rapidly and is in good physical condition antili the disease recurs. The period of immunity frequently extends over many months and occasionally years. By the use of the button the operation of pylorectomy is relieved of its greatest dangers-viz., shock and leakage at the seat of aporoximation. The operation is best performed in the following manner :-First, ligate the mesentery on the upper side of the stomach, pylorus, and duodenum as a broad pedicle with from three to four double ligatures and cut between. Second, ligate the mesentery on the under side in the same manner; the pylorus can then be lifted well up into the abdominal incision. Third, pack thoroughly around with gauze and place two clamps on the stomach, one above and the other below the place to be incised. Fourth, a circular incision is then made in the stomach, including the peritoneum and mascolaris ; this is pushed back half an inch and the mucous membrane cut off ; the latter is rapidly closed with a continuons sature; the serosa and muscularis are then closed with a continuous Lembert. Two clamps are placed on the dudenum and it is excised. Fifth, one half of the button is then placed in the end of the duodenum and the other balf in the posterior wall of the stomach, one inch from the line of sutare, and pressed together. We had four operations of this sind reported, with three recoveries. In all of the latter the batton passed on through the duodenum. The first case was that of Dr. A. H. Ferguson, operated on on July 25th, 1893. The patient is still living and in excellent health, having gained sixty pounds in weight. The second case was that of Dr. Willy Meyer's. The patient died several months after the operation. The third case died five days atter operation. The patient was in an extremely emaciated condition, and though the operation lasted only forty minutes, he was in a critical state all the time nntil he died. The fourth case was reported by Dr. M. H. Everett, Lincoln, Nebraska. The patient, a male, aged thirty-five years, first complained of stomach trouble eleven years ago. He had never been free from pain since. Five years ago he commenced to pomit, and during the five years he had not passed a day without vomiting. He came under my charge in November, 1894. His stomach was very much distended and there was a tumour perceptible at the pylorus. An operation was performed on Dec. 18th, 1894. An incision in the median line four inches in length was made; the tumour was drawn out; there were no adhesions ; the tumour was as large as a small tnkkey egg. The mesentery was ligated and divided. The stomach was incised one inch from the growth, and a CzernyFembert suture used; the duodenum was divided one inch from the growth; an incision in the posterior wall of the stomach was made and the duodenum joined to it with the button; certainly not five minutes were spent in making the anastomosis; the abdomen was closed without drainage. The temperatare next day was $99^{\circ} \mathrm{F}$. for a few hours, after which time it remained normal. The button was passed fourteen days after operation. A wonderful change is noticeable in the man. He has not romited; his appetite is enormous ; and at this day, twenty-two days after operation, he has gained twenty pounds. The tumour was found to be a fibroma.

\section{Cholicystdudodenostomy.}

The operation of cholecystduodenostomy by this method and the results are most satisfactory. We have 38 operations reported for cholelithiasis, with 37 recoveries and 1 death. The patient lived for seven days following the operation. There was continuous hæmorrhage from the laceration of the liver from the separated adhesions. A large quantity of blood was found in the peritoneal cavity post mortem; a perfect union existed between the bowel and the gallbladder, and there was no peritonitis. These results were obtained by twenty-two different operators. In my first article on this subject I recommended the removal of only a sufficient number of gall-stones to allow of the insertion of the button. I early abandoned this method, as I saw that it was possible for calculi to remain in the diverticula of the gallbladder after the button had passed. That this was well grounded was shown in a case referred to me by Dr. J. H Hoelscher. Two years after the operation she was again attacked with colic in the region of the gall-bladder. A cholecystostomy was performed, and two large calculi were fourd in a pocket at the upper end of the cystic duct. The gallbladder from the fundus down to the calculi, a distance of two inches and a half, had contracted to a tube about the diameter

of a lead pencil. The stones were crushed and removed. The patient made an excellent recovery. This is the only case in which there was a recurrence of the symptoms after the operation, and supports the view advanced by me in my original article that the gall-bladder would contract to a tube, and that the opening between the gall-bladder and the intestine would become so small by the contraction of the gall-bladder that it would not admit fæces into the tract. We have had no case of infection of the liver or gall tracts reported as a result of the operation. Failure of union bas not occurred in a single case. This is a most striking contrast in this particular to the results obtained with the suture. The theoretical objection expressed that the button might drop into the gall-bladder and be retained there has not been supported by a single case. The danger of hæmorrhage in patients suffering from cholemia is very great; and the greatest precaution should be exercised in lacerating adhesions in this class of cases, as the hæmorrhage may continue for days and even weeks. The operation of cholecystenterostomy for malignant disease was very unsatisfactory, as there were eight performed with seven deaths. Two died from shock ; one from twisting of the small intestine, producing a volvulus before making the approximation. In one case the gail-bladder was so friable from malignant disease that it tore when the sutures were inserted, and after the button was placed in position and the abdomen closed the friable wall gave way and peritonitis ensued. In all of the others the approximations were found perfect on post-mortem examination. While the mortality from the operation is great, not one of the deaths could have been attributed to the method. Still, they all tend to show that the operation for malignant disease is not a justifiable one ; and in many of my recent exploratory operations, when $I$ have found a large carcinoma in the pancreas, duct, or necir of the gall-bladder, I have abandoned the operation, and all of the patients have survived the exploration. Cholecystenterostomy is contraindicated in gangrene of the gall-bladder. These cases should be opened and drained externally, and the peritonenm thoroughly protected by packing. The indications for the operation of cholecystenterostomy are: (1) obstruction to the common duct; (2) obstruction to the cystic duct, where cholecystectomy is impracticable ; (3) chronic cholecystitis, with thickening of the wall of the gall-bladder; (4) fistula of the gall-bladder where the patient is emaciated from the loss of bile; and (5) carcinoma of head of the pancreas in its early stage.

Intestinal Approximation.

It is in this field that the button has been of the greatest practical value. The pathological conditions demanding it use in this class of cases greatly endanger the life of the patient. The cases may be well classified as follows :(1) Resection of the bowel for gangrene: (a) for internal obstruction, and (b) for hernia; (2) resection of bowel for cure of fæcal fistula; (3) resection for malignant growths; (4) resection for perforations of intestine, both traumatic and pathological; and (5) resection of the rectum. Of the resections for gangrene of the bowel from internal obstruction we have 14 cases with 1 death. The patient was a child that had suffered from a four weeks' obstruction; she was so weak and emaciated when operated upon that she never rallied, and died in twenty-four hours. Of the resections for gangrenous hernia there were 12 cases with 2 deaths. The first case died forty-eight hours after an operation for strangulated umbilical hernia which had perforated into the abdomen; general septic peritonitis existed at the time of the operation. The necropsy showed continuation of peritonitis, perfect approximation, and the button in position. The second case was a very interesting one, the patient having bad a congenital hydrocele of the testicle with an inguinal hernia in a separate sac. The sac of the hydrocele connected with the sac of the hernia at its neck. The patient after a severe exertion found his hernia down and painful. It was reduced in the usual manner, but the pain and vomiting continued. Six days after the obstruction occurred he was brought to me by Dr. Hanna of Winfield, Iowa, who had seen him only a few hours before and made the diagnosis. I found the hernial sac free and empty, but a Littré involving four-fifths of the circumference of the bowel was strangnlated in the small opening of the hydrocele sac. This knuckle had perforated into the sac, and the lining of the sac was gangrenous from the infection. A resection of five inches of intestine was made with an end-to-end approximation, the approximated intestine returned, and the abdomen dressed open. The patient's bowels moved six times within the next eight hours. He did not vomit, bat his palse increased in 
OPERATIONS ON THE IN'LESTINES WITH THE MURPHY BUTTON.

TABLI I.-WESECTION, END-TO-HND APPROXIMATION.

\begin{tabular}{|c|c|c|c|c|c|c|}
\hline : & Date. & Operator. & Diagnosis. & Operation. & | & Remarks. \\
\hline 1 & Dec. 8 ,'92 & Walker & Strangulated hernia $\mathrm{R}$ & Resection of intes- & $1-1$ & First end-to-end approximation by button Oct. 21, 1893. Patient in perfect \\
\hline 2 & April 3, '93 & $\begin{array}{l}\text { Andrews, } \\
\text { E. W. }\end{array}$ & $\begin{array}{l}\text { Femoral hernia, } \\
\text { gaugrene }\end{array}$ & $\begin{array}{l}\text { Resertion of intes } \\
\text { tine, } 18 \text { in. }\end{array}$ & $1-1$ & Nov. 21 , patient in perfect health. \\
\hline 3 & June $5, ' 33$ & Murpliy & $\begin{array}{c}\text { Intestinal strangu- } \\
\text { lation }\end{array}$ & $\begin{array}{l}\text { Resection of intes- } \\
\text { tine } 2 \text { in. }\end{array}$ & $1-1$ & Time for approximation five minutes and a balf. \\
\hline 4 & July 10, '93 & Murphy & $\begin{array}{c}\text { Umbilical bernia. } \\
\text { gangrene, peri- } \\
\text { tonitis }\end{array}$ & $\begin{array}{l}\text { Resertion of intes- } \\
\text { tine, } 5 \text { in. }\end{array}$ & -11 & Forty-eight hours' continued peritonitis ; perfect approximation. \\
\hline 5 & Oct. 17, '93 & Ruth & Tumour of ciecum & $\begin{array}{l}\text { Resection of cacum } \\
\text { and colon, } 2 \text { in. }\end{array}$ & $1-1$ & Nov. 15, excellent health; obstruction six months; child six years. \\
\hline 6 & Nor. 12,93 & Bouffler & $\begin{array}{c}\text { Femoral hernia, nive } \\
\text { dars' obstruction }\end{array}$ & $\begin{array}{l}\text { Resection of intes- } \\
\text { tine, } 4 \text { in. }\end{array}$ & $1-1$ & Time four minutes and a half. \\
\hline 7 & March 25,'93 & Sutton & $\begin{array}{c}\text { Closure of artificial } \\
\text { anus withoutre- } \\
\text { section. }\end{array}$ & Lateral anastomosis & $1-$ & Aug. 20, excellent health. \\
\hline 8 & Sept. 10, '93 & Murphy & Frecal tistula & $\begin{array}{l}\text { Lateral anastomosis } \\
\text { without resertion }\end{array}$ & $1-1$ & Time six minutes; Oct. 24 , well; fistula closed. \\
\hline 9 & '93 & Rngers & $\begin{array}{l}\text { Inguinal hernia, } \\
\text { gangrene }\end{array}$ & $\begin{array}{l}\text { Resertion of intes- } \\
\text { tine, } 10 \mathrm{in.}\end{array}$ & $1-1$ & Button passed seventh day. \\
\hline $\begin{array}{l}10 \\
11\end{array}$ & $\begin{array}{l}\text { Sept. 23, '93 } \\
\text { July, } 93\end{array}$ & $\begin{array}{l}\text { Murphy } \\
\text { Mecall }\end{array}$ & $\begin{array}{c}\text { Fecal fistula } \\
\text { Fwcal fistula, gan- } \\
\text { grene }\end{array}$ & $\begin{array}{l}\text { Lateral auastomosis } \\
\text { Lateral anastomosis }\end{array}$ & $1-$ & Time seven minutes. \\
\hline 16 & Oct., '93 & Marcy & Cancer of rectum & $\begin{array}{l}\text { Resection of rectum, } \\
4 \mathrm{in.}\end{array}$ & $1-1$ & Discharged twentieth day. \\
\hline $\mathbf{1}^{7}$ & Nor. 16, '93 & Cordier, A.H. & $\begin{array}{c}\text { Cicatricial band of } \mathbf{E} \\
\text { ileum }\end{array}$ & Entero-enterostomy & $1-$ & 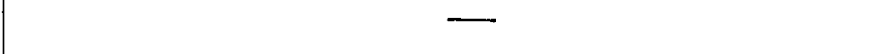 \\
\hline $1 \%$ & July 8,'93 & Pacon & Stricture of rectum & $\begin{array}{l}\text { Bacon's operation } \\
\text { on rectum }\end{array}$ & $1-$ & $\begin{array}{l}\text { May 31st, good calibre; neither pain nor discharge; rectum soft ande } \\
\text { pliable. }\end{array}$ \\
\hline 15 & Jan. 14, '93 & Murpuy & $\begin{array}{l}\text { Annular stricture } \\
\text { of rectum }\end{array}$ & $\begin{array}{l}\text { Application of } \\
\text { huttonl }\end{array}$ & $1-$ & 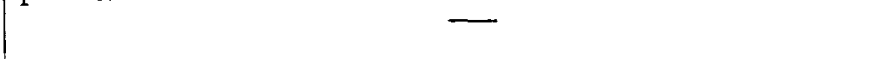 \\
\hline 16 & Sept., '93 & Deck, $\mathbf{C}$ & $\begin{array}{c}\text { Carrinoma of } \\
\text { pylorus }\end{array}$ & Maydl's operation & ] -1 & $\begin{array}{l}\text { Died subsequently from cancer; post mortem perfect union where button } \\
\text { was used ; no peritoneal adhesion. }\end{array}$ \\
\hline $\begin{array}{l}17 \\
1 \xi\end{array}$ & $\begin{array}{l}\text { Dec. 11, } 93 \\
\text { Feb. } 93\end{array}$ & $\begin{array}{l}\text { Ferguson } \\
\text { Brrk, C. }\end{array}$ & $\begin{array}{l}\text { Canrer of careum } \\
\text { Fircal fistula }\end{array}$ & $\begin{array}{l}\text { Resection of crcum } \\
\text { Duod-iejunostomy }\end{array}$ & $1-$ & Button passed twentieth dav $\quad-$ \\
\hline 16 & Jan. 14, 94 & Fogutson & Firral tistula & ileum & & \\
\hline 2C & Jan. 30,' 93 & Keen, & $\begin{array}{l}\text { of hepa- } \\
\text { of colon }\end{array}$ & omy & $1-1$. & Death forty-seren days later; ulcer of ascending colon; perforation. \\
\hline 21 & Fel. 3, ‘4 & Price, J. & $\begin{array}{c}\text { Sarcoma of sigmoid } \\
\text { flexure }\end{array}$ & $\begin{array}{l}\text { Resection, } 6 \text { in. of } \\
\text { sigmoid }\end{array}$ & & Button passed ninth day. \\
\hline 22 & Feb. 24, '94 & Nezer, W. & $\begin{array}{c}\text { Carcinoma of } \\
\text { pylorus }\end{array}$ & Pylorectomy & $1:-$ & Button voided twenty-first day. \\
\hline 23 & March 3, 94 & Meyer, W. & Sarconia of ileum & Resection, $15 \mathrm{in}$. of & 1 & $\ldots$ \\
\hline 24 & Jan. 2, '94 & Dodge, IV. T. & Facal tistula & $\begin{array}{c}\text { Resection, } 3 \text { in. of } \\
\text { ileum }\end{array}$ & $1-$ & Button voided eighth day. \\
\hline 26 & Fel. 16, ${ }^{\prime} 94$ & Dodge, W. T. & Fical fistula & $\begin{array}{c}\text { Resection, } 3 \text { in. of } \\
\text { colon }\end{array}$ & $1-$ & Button passed eighth day. \\
\hline $2 E$ & May, '94 & Dodge, W. T. & $\begin{array}{l}\text { Ileum adherent to } \\
\text { oval ian cyst }\end{array}$ & $\begin{array}{c}\text { Resection of } \\
\text { ileum }\end{array}$ & $1-$ & $\begin{array}{l}\text { Patient died eleven days later from complication; union perfect; buttons } \\
\text { found in rectum. }\end{array}$ \\
\hline 21 & ${ }^{*} J a n .15, ' 94$ & Lane, W. A. & $\begin{array}{c}\text { Sarcoma of meso- } \\
\text { sigmoid }\end{array}$ & $\begin{array}{l}\text { Resection, } 12 \text { in. of } \\
\text { colonl }\end{array}$ & ] - & Button voided on eighth day. \\
\hline 28 & May 9, '94 & Bryunt, J. D. & $\begin{array}{l}\text { Frecal tistula (had } \\
\text { five previous } \\
\text { operations) }\end{array}$ & Ileo-colostomy & $1-$ & Oblong button used for first time; passed on fifteenth day. \\
\hline 29 & May 14, '94 & Shrady, G. F. & Fiteal tistula & $\begin{array}{l}\text { Lateral approxima- } \\
\text { tion }\end{array}$ & $1-$ & - \\
\hline 30 & $\begin{array}{l}\text { Feb. 12, '94 } \\
\text { April } 27,94\end{array}$ & McBurney, $\mathrm{C}$. & 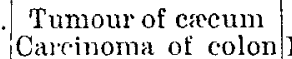 & tomy & -1 & $\begin{array}{l}\text { Infection occurred; see details in history. } \\
\text { Growth to be resected. }\end{array}$ \\
\hline 32 & Dec. 12, '93 & McDinineys & Frecal fistuld & $\begin{array}{l}\text { Lateral approxima- } \\
\text { tion }\end{array}$ & 1 & passed on ninth day through fistula. \\
\hline 33 & April 1, '94 & Davis & $\begin{array}{l}\text { Adherent ovarian } \\
\text { ('yst }\end{array}$ & Entero-enterostomy & 1 & \\
\hline 34 & Feb. 28, '94 & McLaren & Strangu & terostomy & $1-$ & Six inches of sigmoid removed. \\
\hline 35 & Nov. 11, ${ }^{9} 93$ & (1. & $\begin{array}{c}\text { Carcinoma of ileum, } \\
\text { obstruction }\end{array}$ & Resection, end to & -1 & Time for operation ten minutes; death from shock in \\
\hline 36 & Jan. $29,{ }^{\prime} 94$ & $\begin{array}{l}\text { Middleton, } \\
\text { W. I. }\end{array}$ & $\begin{array}{c}\text { Careinoma of } \\
\text { rect um }\end{array}$ & $\begin{array}{l}\text { Resection of upper } \\
\text { part of rectum }\end{array}$ & $1-$ & Resection, $2 \frac{1}{2}$ in.; completely cured; button passed on twelfth day. \\
\hline 37 & Feb. 27, '94 & $\begin{array}{l}\text { Fergusuln, } \\
\text { A. H. }\end{array}$ & Cancer of cacum & $\begin{array}{l}\text { Extirpation of } \\
\text { cacum, } 14 \text { in. of } \\
\text { bowel }\end{array}$ & $1-$ & $\begin{array}{l}\text { Death four weeks later, diarrhoea; necropsy-perfect approximation; } \\
\text { opening large as button. }\end{array}$ \\
\hline 38 & Feb. 27, '94 & $\begin{array}{l}\text { Stewart, } \\
\text { W. W. }\end{array}$ & Gangrenous hernia & $\begin{array}{l}\text { Resection, } 10 \mathrm{in} . \\
\text { small }\end{array}$ & $1-$ & $\begin{array}{l}\text { Patient in extreme condilion; button passed thirteenth day; rapid con- } \\
\text { valescence. }\end{array}$ \\
\hline 39 & March, '94 & $\begin{array}{l}\text { Retd, Chas. } \\
\text { A. H. }\end{array}$ & Carcinoma of caecum & $\begin{array}{c}\text { Resection of part of } \\
\text { carcum }\end{array}$ & $1-$ & gassed twenty-second day. \\
\hline $4 C$ & Mar & Coptland & - & & $1-$ & \\
\hline 41 & $A_{1}$ & tou & $\begin{array}{l}\text { Neoplasm of mesen- } \\
\text { tery }\end{array}$ & $\begin{array}{l}\text { Resection, end to } \\
\text { end }\end{array}$ & $i-$ & Button passed fourteenth day; patient small child. \\
\hline 42 & April 7, '94 & Dt-nnis & strangulated hernia & Resection of ileum & $1-$ & $\begin{array}{l}\text { Button passed twenty-second day; wound suppurated; facal fistu'a } \\
\text { closed twenty-seventh day. }\end{array}$ \\
\hline 43 & May 11, '94 & Outeruriage & $\begin{array}{c}\text { Carcinoma of trans- } \\
\text { verse colon }\end{array}$ & $\begin{array}{c}\text { Resection, end to } \\
\text { end }\end{array}$ & $1-$ & $\begin{array}{l}\text { Time for oper ation one hour forty-five minutes; several inches of traus- } \\
\text { verse colon resected. }\end{array}$ \\
\hline 44 & May 12, '94 & Meyer, W. & $\begin{array}{c}\text { Intussisception, } \\
\text { myxo-sarcoma }\end{array}$ & $\begin{array}{l}\text { Resection of ileum, } \\
3 \text { in. }\end{array}$ & $1-$ & Button passed eleventh day ; perfect recovery. \\
\hline 45 & June 1, '94 & Coub, J. O. & Syphilit.c stricture & $\begin{array}{c}\text { Ana tomosis aroune } \\
\text { stricture }\end{array}$ & $1-$ & Died fourteen days after, pneumonia ; anastomosis perfect. \\
\hline 46 & June 4, '94 & Murphy, J. B. & Fiecal fistula & Resection, end to & $1-$ & $\begin{array}{l}25 \text { in. of small intestine removed. Opening made by button in pro- } \\
\text { vious operation dilated from } 3 \frac{1}{4} \text { to } 5 \text { in. }\end{array}$ \\
\hline 47 & June 13, '94 & Shimoneck, $\mathbf{F}$ & Strangulated hernia & $\begin{array}{l}\text { Rrsection, end ana- } \\
\text { stomosis }\end{array}$ & $1-$ & Button passed on eighteenth day. \\
\hline 48. & June 15, '94 & $\begin{array}{l}\text { MeCallum, } \\
\text { J.L. }\end{array}$ & $\begin{array}{l}\text { Strangulation of } \\
\text { ileum }\end{array}$ & $\begin{array}{l}\text { Resection, end to } \\
\text { end }\end{array}$ & $1-$ & 12 inches of ileum resected. \\
\hline 49 & June $16, ' 94$ & Meyer, $w$. & $\begin{array}{l}\text { Intestinal obstruc- } \\
\text { tion, sarcoma, in- } \\
\text { tussusception }\end{array}$ & $\begin{array}{l}\text { Resect on. ascend- } \\
\text { ing colon, } 12 \text { in. }\end{array}$ & $1-$ & $\begin{array}{l}\text { Button passed eleventh day; discharged July 24th; died of marasmus } \\
\text { Aug. 14th, 1894; neeropsy, multiple sarcoma. }\end{array}$ \\
\hline 50 & June 17, '94 & Davis, F. A. & $\begin{array}{c}\text { Penetrating wound } \\
\text { of abdonen, lacera- } \\
\text { t'un of intestine }\end{array}$ & $\begin{array}{c}\text { Resection, end to } \\
\text { end }\end{array}$ & -1 & 1 Patient never rallied from shock caused by injury, and died in three hours. \\
\hline 51 & June 18, '94 & Lilienthal & $\begin{array}{c}\text { Carcinoma of trans- } \\
\text { verse colon }\end{array}$ & $\begin{array}{l}\text { Resection, } 6 \text { in. } \\
\text { transverse colon }\end{array}$ & $1 \cdot-$ & - Button used 1 in. in diameter; passed eighteenth day without pain. \\
\hline $5^{r}$ & June $21, ' 94$ & $\begin{array}{l}\text { Corhems, } \\
\text { F W. }\end{array}$ & Strangulated uernia & $\begin{array}{l}\text { Resectin end to } \\
\text { end }\end{array}$ & $1-$ & - Resection of 26 in. ; button passed 180 hours after operation. \\
\hline
\end{tabular}


OPERATIONS ON THE INIESTINES WITH THE MURPHY BUTTON-continued.

Table I.-Reisection, End-To-end Approximation-continued.

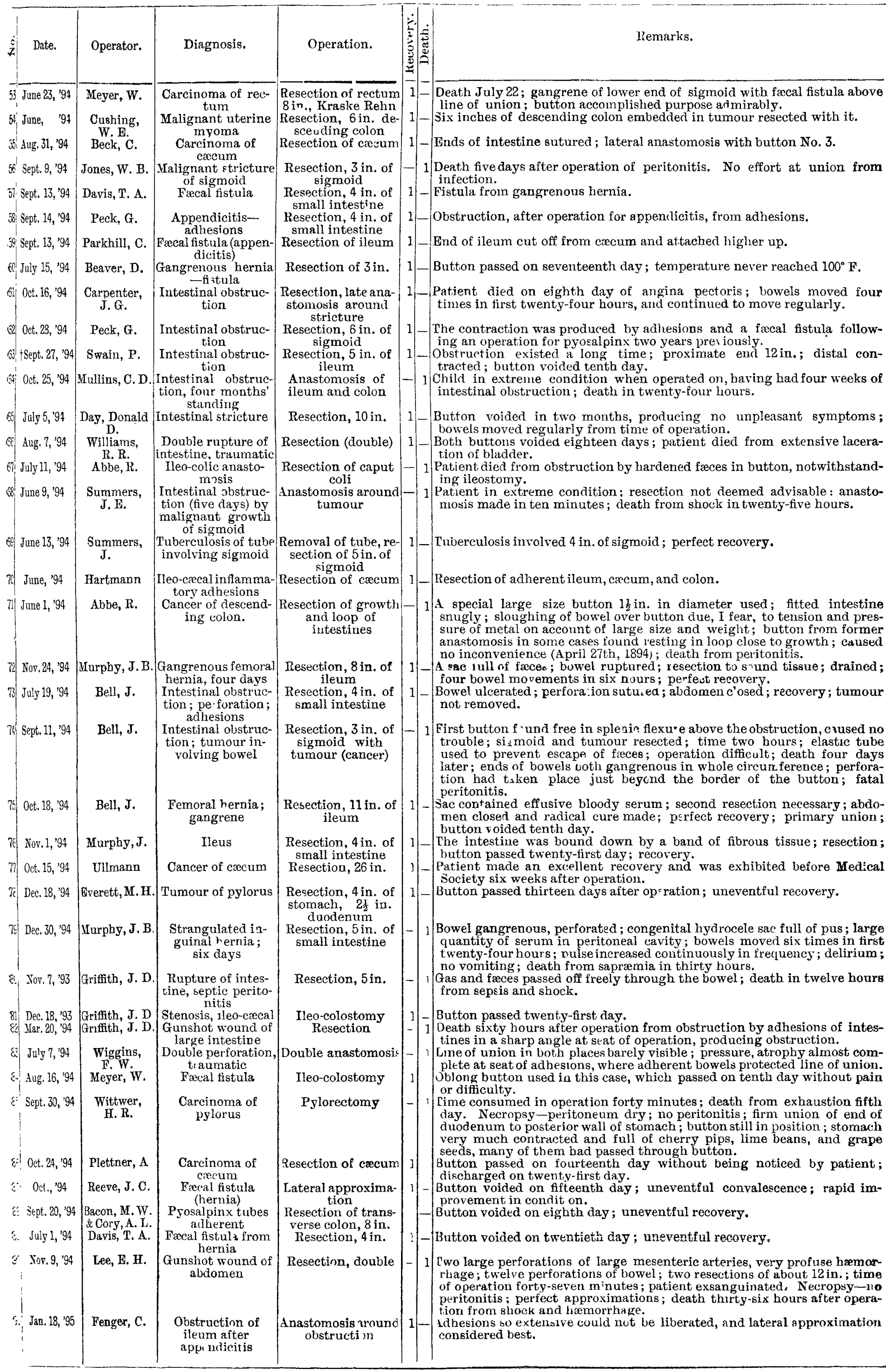




\section{OPERATIONS ON THE INTESTINES WITH THE MURPHY BUTTON-continued.}

Table II.-Cholgcystentmostomies in Non-Malignant Cases.

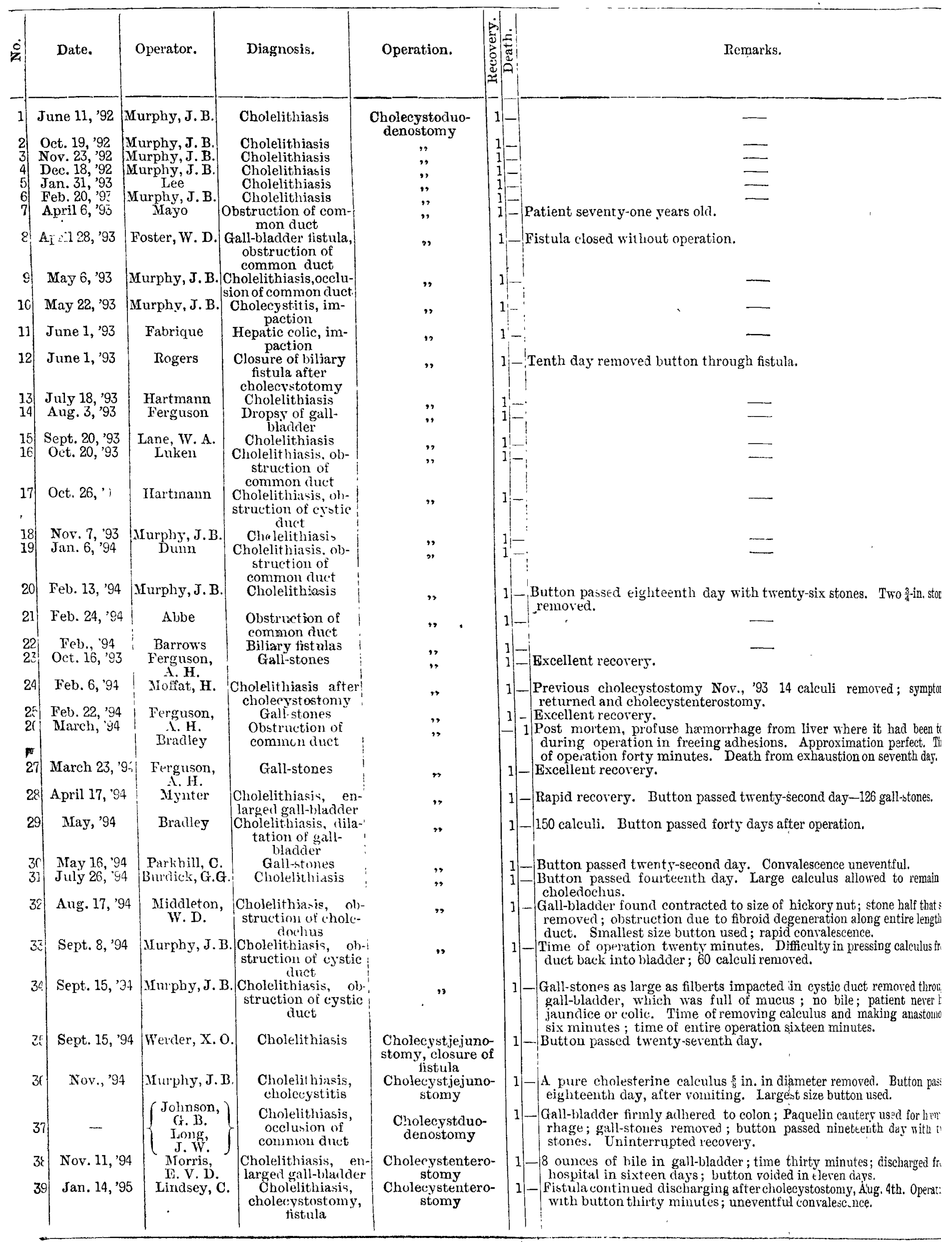


OPERATIONS ON THE INTESTINES WITH THE MURPHY BUTTON-continued.

Table IU.-Cholecystenterostomihs in Malignant Cashs.

\begin{tabular}{|c|c|c|c|c|c|}
\hline Date. & Operator. & Diagnosis. & Operation. & 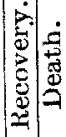 & Remarks. \\
\hline Uarch, 93 & Weir & $\begin{array}{c}\text { Cancer of pancreas, } \\
\text { liver, onentum, } \\
\text { and gill-ducts }\end{array}$ & $\begin{array}{l}\text { Cholecystentero- } \\
\text { stomy }\end{array}$ & -1 & 1 Exhaustion; perfect approximation. \\
\hline 2 Lay, 93 & Murphy, J.B. & $\begin{array}{c}\text { Cancer of duode- } \\
\text { num, pancreas, gall- } \\
\text { ducts, and liver }\end{array}$ & $\begin{array}{l}\text { Cholecystojejuno- } \\
\text { stomy }\end{array}$ & -1 & l Four days; ileus from volvulus; loop of jejumum twister upon itself. \\
\hline & King, E. W. & $\begin{array}{c}\text { Carcinoma of } \\
\text { pancreas }\end{array}$ & $\begin{array}{l}\text { Cholecystduode. } \\
\text { nostomy }\end{array}$ & -1 & $\begin{array}{l}1 \text { No peritonitis; cholamic hæmorrhage from all mucous surfaces of the } \\
\text { hody; death on fourth day. }\end{array}$ \\
\hline Narch, 94 & Mynter & $\begin{array}{c}\text { Stenosis of } \\
\text { common duct }\end{array}$ & $\begin{array}{l}\text { Cholecystduode- } \\
\text { nostomy }\end{array}$ & & $\begin{array}{l}1 \text { No peritonitis ; perfect anhesions; multiple carcinoma of pancreas and } \\
\text { liver; death from prostration. }\end{array}$ \\
\hline Sept. 24, '94 & Hartley, $\mathrm{F}$. & $\begin{array}{l}\text { Malignant obstruc- } \\
\text { tion of commun duct }\end{array}$ & $\begin{array}{l}\text { Cholecystcolo- } \\
\text { stomy }\end{array}$ & $1-$ & Button passed. \\
\hline f' Jan., '93. & $\begin{array}{l}\text { Dawbarn, } \\
\text { R. H. II. }\end{array}$ & Cholelithiasis & $\begin{array}{l}\text { Cholecystduode- } \\
\text { nostomy }\end{array}$ & -1 & $\begin{array}{l}\text { It was found on introducing the suture that a carcinoma of the gall- } \\
\text { bladder as well as gall-stones existed. When the sutures were intro- } \\
\text { duced they tore through the cancerous wall as if it were wet paper; the } \\
\text { smallest sized button was finally placed and the intestine approximated; } \\
\text { death from septic peritonitis ; necropsy showed the friable gall-bladder } \\
\text { gare way from the clasp of the button. As far as I can learn this was } \\
\text { the first time the button was used in New York. Dr. Dawbarn } \\
\text { comments : "This case should not count against the method for the } \\
\text { reasons mentioned; I have repeatedly demonstrated upon the cadaver } \\
\text { that the operation is simplicity itself." }\end{array}$ \\
\hline ? Feb. 27, 93 & Griffith, J. D. & $\begin{array}{l}\text { Cholelithiasis, } \\
\text { cholæmia }\end{array}$ & $\begin{array}{l}\text { Cholecystentero- } \\
\text { stomy }\end{array}$ & -1 & $\begin{array}{l}1 \text { Patient had large hamorilagic spots all over body at time of operation; } \\
\text { necropsy showed large extravasauions throughout entire intestine track; } \\
\text { no peritonitis; death from exhaustion. }\end{array}$ \\
\hline 8. Warch 13, '93 & Griffith, J.D. & $\begin{array}{c}\text { Cholelithiasis, } \\
\text { impaction of stone } \\
\text { in duct }\end{array}$ & $\begin{array}{l}\text { Cholecystentero- } \\
\text { stoiny }\end{array}$ & -1 & $\begin{array}{l}1 \text { Operation greatly prolonged on account of adhesions; connexion to } \\
\text { jejunum. }\end{array}$ \\
\hline
\end{tabular}

\section{TABLE IV.-GaNGRENe OF THE GALL-BLADDER.}

\begin{tabular}{c|c|c|c|c|c}
\hline lXarch 15, ,94 Long, J. & $\begin{array}{c}\text { Gangrene of gall- } \\
\text { bladder }\end{array}$ & $\begin{array}{c}\text { Resection of gan- } \\
\text { grenous portion; } \\
\text { cholecystentero- } \\
\text { stomy }\end{array}$ & -1 & 1 & $\begin{array}{c}\text { Gall-bladider extensively gangrenons; contained 196 calculi ; death } \\
\text { in twenty-four hours; temperature reached 106 ; sepsis. }\end{array}$ \\
\hline
\end{tabular}

TABLE V.-GAgTRO-RNTEROSTOMY.

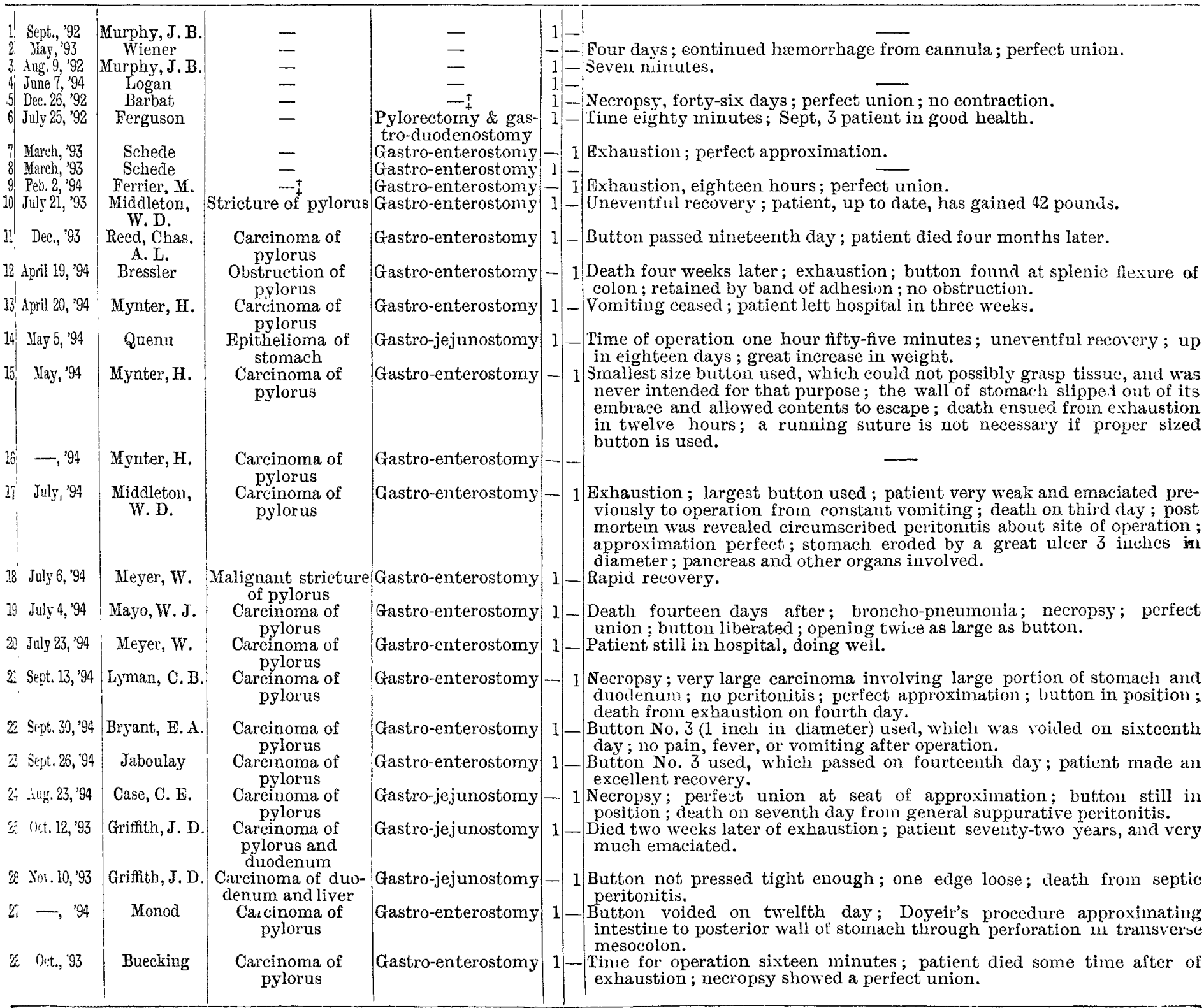

I Dr. Murphy's table omits the diagnosis of these nine cases and the operation in the first five. 
frequency, and he died thirty hours after the operation with all of the symptoms of auto-intoxication from the decomposing proteids that had been retained in the alimentary canal. There was no peritonitis. This case shows how important it is to act upon the symptoms of obstruction following an apparently complete reduction of a hernia. of resections for frcal fistula with end-to-end approximation I have had nine cases reported, all of which recovered. Here the results show that the operation of resection with end-to-end approximation promises much more for the patient than the lateral approximation both for the imme. diate relief of the fistula and the permanent cure, and I now perform it in all cases in preference to the lateral. We have a total of 41 resections for non-malignant diseases, with 2 deaths. If to these be added the seven cases by Dr. Joseph Price, the details of which I have not received, with six recoveries, we have a total of 48 cases with 3 deaths. 'The first death was due to continaed peritonitis and the second to auto-intoxication. In Dr. Price's case the death occurred from shock twelve hours after operation. The operation was the removal of an enormous universally adherent fibroid, also the excision of several inches of the bowel and a portion of cne ureter. These results, obtained in the hands of many operators, certainly indicate that the question of operation in gangrenous hernia, internal obstruction, and fecsal fistula is definitely settled-i.e., that resection with end-to-end approximation gives all that can be expected in the way of results.

Resection of the intestine for malignant disease with end-to-end approximation does not give us as good results as for non-malignant, as is the case with all operaticns for malignant disease. Still, when we review and analy se them, they are a great improvement over those obtained by other methods, and on the whole verv satisfactory. There were 30 operations with 7 deaths. I'nese include 8 resections of the cæcom with one death. The causes of death in the malignant cases were as follows. In one case infection from withcut during operation; a perfect approximation was found at the necropsy. Ore case from shock ten hours after operation. One case from peritonitis. The specimen showed that there was no evidence of effort at unicn at the seat of approximation, and that the peritonitis was present from the time of operation. In one case which died from peritonitis a special large-cize button (one inch and a half in diameter) was used; it fitted the intestine too tightly and produced a sloughing over the surface of the button with perforation. It is important that the button should fit easily in the intestine. One case had fatal peritonitis. The gangrene of both ends of the bowel was attributed to the length of time that the ends were corrpressed during the operation, and this conclusion is certainiy supported by the fact that both ends were gangrenous and that the perforation occurred not at the seat of the pressure atrophy, but beyond the margin of the button. The intestinal clamps which I use on the intestine to prevent the escape of fæces and gas cannot produce this condition, as they do not compress the parallel artery of the bowel in the triangle made up by the division of the peritoneal surfaces of the mesentery and the wall of the bowel. This artery is the most important one for the nutrition of the bowel. In one case death occurred shortly after operation, but the cause was not reported. Finally, one case died from exhaustion. Resection for perforations of intestine, traumatic and pathological, with end-to-end approximation. The mortality from perforations, both from gunshot wounds and for perforating ulcers, has alway been very great, not that the danger exists in the operation, but in the dangers of the pathological conditions themselves. Luche, in his collection of 322 cases, found that where the operation was performed within twelve hours after the perforation the mortality was 58.2 per cent. later than twelve hours, 79.5 per cent. In bullet wounds of the abdomen the collapsed condition of the patient, the profuse bæmorrhage, and the shock upon the nervous system all contribute very greatly to the mortality. We can estimate with great accuracy the position of the wound in the bowel by calculating the course of the bullet from the point of entrance to the position in which it is lodged. The bullet commonly passes either (1) from before backwards, in which case we have one or two perforations, or (2) transversely, then we have many perforations in close proximity-i.e., we may have as many as ten or twelve perforations within twenty jnches of intestine. 'l'he operation should be a resection of the entire perforated coil, an end-to-end approximation, with d. a nage of the cavity. Where the penforations are a greater distance apart double resections may be made and two buttons inserted as in a case reported by Dr. R. R. Williams of Manning, Iowa. The operations for pathological perforation of the intestinal tract are, as a rule, postponed too long. The profession bas not yet extricated itself from the erroneous belief that the symptoms of collapse occur immediately after the perforation takes place. I would enunciate the following rule, and it should be impressed on the mind of every practitioner. The manifestations of perforation into the peritoneal cavity depend upon the character and quantity of material admitten into the cavity and the pathological changes pro. duced thereby in the peritoneam. By this I mean that the symptoms are not the result of the perforation per se, but the result of the pathological changes produced by the result of the perforation.

\section{LATERAL ApPROXIMATION.}

In cases of frcal fistula resection should be performed in preference to lateral apposition; the same is true in cases of malignant disease. In cases of extensive adbesions it may be impracticable to resect, and lateral appoximation must be performed. Of lateral approximations 12 were reported: 5 for maligant disease, with 2 deaths, and 7 for simple obstruction; all recovered.

\section{Resection OF THE RECTUM.}

This operation has been simplified in its most trying mechanical part-i. e., the drawing down and approximating the upper to the lower segment, suturing it there, and still retaining the sphincter intact. We have reported 3 resections with recoveries, and 2 lateral approximations; that is approximations around the strictures with a pressure atropby of the stricture, a method in which the button is aced, devised and described by Dr. Bacon. ${ }^{1}$ The operation of resection with removal of the sacrum (Kraske) and end-to-end approximation with the bu'ton was first done by Dr. Henry 0 . Marcy of Boston. ${ }^{2}$ The method of procedure for resection of the rectum is as follows:-1. In order to do the operation without removing the coccyx or sacrum (Kraske), it is necessary to be able to reach the upper margin of the carcinoma with the index finger. 2 The sphincter should be dilated until it is completely paralysed; the cancer shou'd be drawn down with forceps, and the rectum packed with gauze above. 3. A puckering string should be inserted in and out through the wall of the rectum half an inch below the carcinoma and left perfectly loose. 4. A circular incision is now made through the entire wall of the rectum, a quarter of an inch above the suture, and between it ard the carcinoma. 5. The carcinoma and rectum are then liberated from the surrounding connective tissue, and drawn. down as a cylinder into the lower segment of the rectum, and the separation continued until well above the carcinoma. 6. Half an inch above the carcinoma anotber puckering string is inserted, and a circular incision is made a quarter of an inch below this, cutting out the carcinoma. The gauze packing is then removed. The male portion of the button in which is threaded extremely heavy braided silk, donble-drawn through the cylinder, is placed above, and the upper packering string tied around the cylinder of the butto and cut short. The stem is held with a small forceps. 7. Slide the female portion of the button over the string and press it up until it barely catches the end of the male cylinder, just sufficient to hold. 8. Make a small parallel incision in the lower segment of the rectum over the coccyx and half an inch below the first puckering string inserted. Through this pass a strand of iodoform gauze for drainage ontside of the button. (This may be removed on the third or fourth day, if necessary.) 9. Draw the button well down and tie the first puckering string around the conjoined cylinders; cat the suture short and press the button together by making traction on the cord and pressing ap from below. 10. Have the bowels loose before the operation and keep them loose after the operation until the button loosens itself or can be liberated by slight traction about the tenth day. The traction cords may be left in until the button is removed.

\section{Conchusrons.}

1. The cicatrix produced with the button does not contract.

2. Size No. 1, $\frac{3}{4}$ in., or No. $2, \frac{1}{1}$ in., should be ased for cholecystenterostomy. I prefer No. 2 .

3 Find to end, side to side, and end to side of the small intestines should be made with button No. $3, \frac{15}{10} \mathrm{in}$. in diameter.

1 The New York Medical Record, Dec. 10th, 1892. 2 Medical Record, June 26th, 1894 
4. Fnd to end and side to side of large intestine should be made with batton No. 4. 1 in. in diameter.

5. A special large size, $1 \frac{1}{4}$ in. in diameter, with a long male cylinder, may be used in some cases of resection of the rectum with advantage, but it should not be used unless it fits loosely.

6 . In intestinal obstruction resection with end to end union gives better results than lateral approximation, and should always be performed when practicable. The same peration should always be done in gangrenons hernia. In facal fistula the bowel shonld be resected and united end to end.

7. The patients should receive liquid nourishment as soon as the effect of the anæsthetic passes off, The bowels should be made to move as soon as possible after the operation and trequent evacuations kept up.

8. If the button does not pass in three or four weeks, the rectum should be examined, as it may rest just inside the sphincter.

9. There bas been one case reported of occlusion of the button by fæcal impaction in the cylinder. This can be easily aroided by a mild cathartic immediately after operation.

10. When returning the intestines to the abdomen, they should be placed in parallel lines, especially at the seat of approximation, to prevent sharp curves and obstruction. This occurred once with the button; many are reported following suture.

11. There is no danger from obstruction from the button, as not a single case has been reported. This proves that the dednctions made by Choput of Pais from experiments on the cadaver are erroneous.

12. There is no danger of extension of the pressure atrophy beyond the line of pressure.

13. Primary adhesion may be hastened in malignant cases by abrading the peritoneum with a needle. It is unnecessary in non-malignant cases.

14. A supporting suture is never necessary to secure union, and should only be used to relieve tension when the riscera approximated are forced ont of position.

15. The mucous membrane should be pushed down in the cup of the button before closing it; if redundant it should be trimmed off with the scissors. It should never be allowed to protrade between the edges of the button when the button is closed.

16. While the button is easily inserted, the pathological condition requiring the operation may demand the greatest surgical skill to secure a favourable result.

17. The following points regarding the construction of the button should be noted before using it. (a) The spring catches should hold firmly in all positions and should be made of a metal that will not be corroded by acids. (b) The elastic pressure cup should be on the male half of the button - never on the female. (c) The edges of the pressure surfaces should be very smooth-hemispherical in shape. (d) The spring under the pressure cap should not be too strong. (e) There have been defective buttons on the market. The following firms are at present manufacturing perfect buttons : J. J. Rgan and Co., Chicago; Truax Greene and Co., Chicago; Geo. Tiemann and Co., New York; W. F. Ford and Co. New York; Down Brothers, London, Kngland Sharp, Smith and Co., Chic ago ; Franz, Kratzmuller and Co., Chicago and Berlin.

18. If the button appears at the opening of the fistula after lateral approximation, do not try to force it through the opening-it is unsurgical ; open the abdomen and (a) press the button back to the anastomotic opening and through the latter on down the intestine, and it will pass ; or (b) make a longitudinal incision in the bowel and take it out.

The Lincoli County Hospital.-From the 125th annual report of this hospital we learn that the number of patients admitted during the past year was 982 , the largest ever admitted since the erection of the institation, and an increase of 142 as compared with those admitted the previous year. Including those remaining as in-patients at the beginning of the year, the total number treated was 1068 ; of these, 481 were cured, 91 relieved, 319 made outpatients, 32 died, 65 were discharged unrelieved, and 80 remained in hospital at the close of the year. The average length of residence in the hospital of each patient was five weeks, and the weekly cost of maintenance $£ 12 s$. $2 \frac{1}{2} l$, as compared with $£ 13 s .7 d$. the preceding year. The total number of out-patients was 4093 .

\section{MALIGNANT DISEASE OF THE COLON SIMULATING MOVABLE KIDNEY.}

BY HENRY MORRIS, M.A., M.B., F.R.C S. ENG., SURGEON TO TIIE MIDDLESEX IIOSPITAL.

CAsE 1. Malignant disease of the ascending colon mistaken for movable kidney and causing a large perinephric abscess. On Oct. 20th, 1889, I was asked to see a married woman aged about forty-three years, who was suffering from a large swelling in the right lumbar region which had been treated as a movable kidney for some months previously. She had recently partly recovered from a severe attack of right-sided pleurisy, and had gone to Worthing for change of air ; but a few days after her arrival at the seaside she became very ill with fever, rigors, and a rapidly developing swelling of great size in the right side of the abdomen. She was seen by Mr. Augustus H. Collet, who sent her home in an invalid carriage and communicated with me to take charge of the case. When I saw the patient she was in great distress with much fever, shivering, and considerable odema of the right loin. The whole right side of the abdomen was distended and dull, and in front there conld be readily felt a hard movable mass not unlike the kidney, but situated rather lower than the normal position of that organ. I was told that this somewhat reniform mass had been known to exist for several months, that it had been very movable, and had been regarded by a distinguished obstetric physician and by a general physician as a movable kidney. 'The large general swelling, with pain, sense of fulness, and cdema in the loin, had only made itself evident a few days. I regarded the case as one of perinephric abscess, and advised that it should be immediately opened, but suggested a physician seeing her before the operation, and Dr. Wilks was accordingly called into consultation. Dr. Wilks agreed that an incision should be made through the loin. This was done on the following day. A very large quantity of pus was evacuated, and two enormous pieces of sioughed cellular tissue were withdrawn. These, when spread out, were large enough to cover a full-sized joint dish. The movable mass was felt to be riding upon the front of this abscess, and sank back into the loin after the evacuation of the pus and when the patient was turned upon her back. The abscess soon healed; the patient immediately improved and became convalescent, but there was no appreciable change in the size of the movable mass. On Dec. 26 th there was evidence of renewed inflammation in the loin; a fresh abscess formed and burst on the night of Dec. $29 \mathrm{th}$, through the centre of the scar of the incision. The second abscess soon healed, but still the mass remained, and, after another consultation with Dr. Wilks on Jan. 25th, 1890, it was decided to examine this by laparotomy. On Jan. 28th Mr. Norton gave the aræsthetic, and with the assistance of $\mathrm{Mr}$. Andrew Clark and $\mathrm{Mr}$. Leopold Hudson I made an incision in the right semilunar line to explore the tumour. It proved to be a broad, annular, malignant growth in the wall of the ascending colon and cæcum, and though still movable at its anterior surface it was very tightly bound down by adhesions posteriorly, so that for this reason, as well as on account of the extent of the infiltration of the bowel, excision was not deemed advisable. There was no occasion to perform colotomy as there was no intestinal obstruction. On Feb. 5th all the sutures were removed, and the patient was convalescent from the exploratory operation. The subsequent symutoms were pain, occasional constipation, flatulence, and general weakness, and towards the end emaciation, but no intestinal obstruction thronghout the illness. She died on August 13th, 1890, somewhat rapidly, and with symptoms suggestive of ulceration and perforation of the bowel.

CAst 2. Cancer of descending colon simulating movable kidney in front of perintphric abscess. - A gentleman fortyseven years of age was sent to me by Mr. Court of Staveley on Feb. 1st, 1887, with the following history. During the preceding six months the patient had suffered on and off with a pain in the left ilio-costal space. About four months ago he had an attack of colic, the pain being in front of the abdomen. He bad always been temperate. He had lost about two stones in weight during the six months and had become weaker. For some time a hard smooth mass had been $f \in I t$, on deep pressure, immediately below the ribs, associated with some $t \in n d e r-$ ness on firm pressure on the loin. He had not been cqual to 